\title{
Nontraumatic hypertrophic neuroma in treated Hansen disease
}

Figure $1 \quad$ MRI and nerve ultrasound reveal sural nerve enlargement

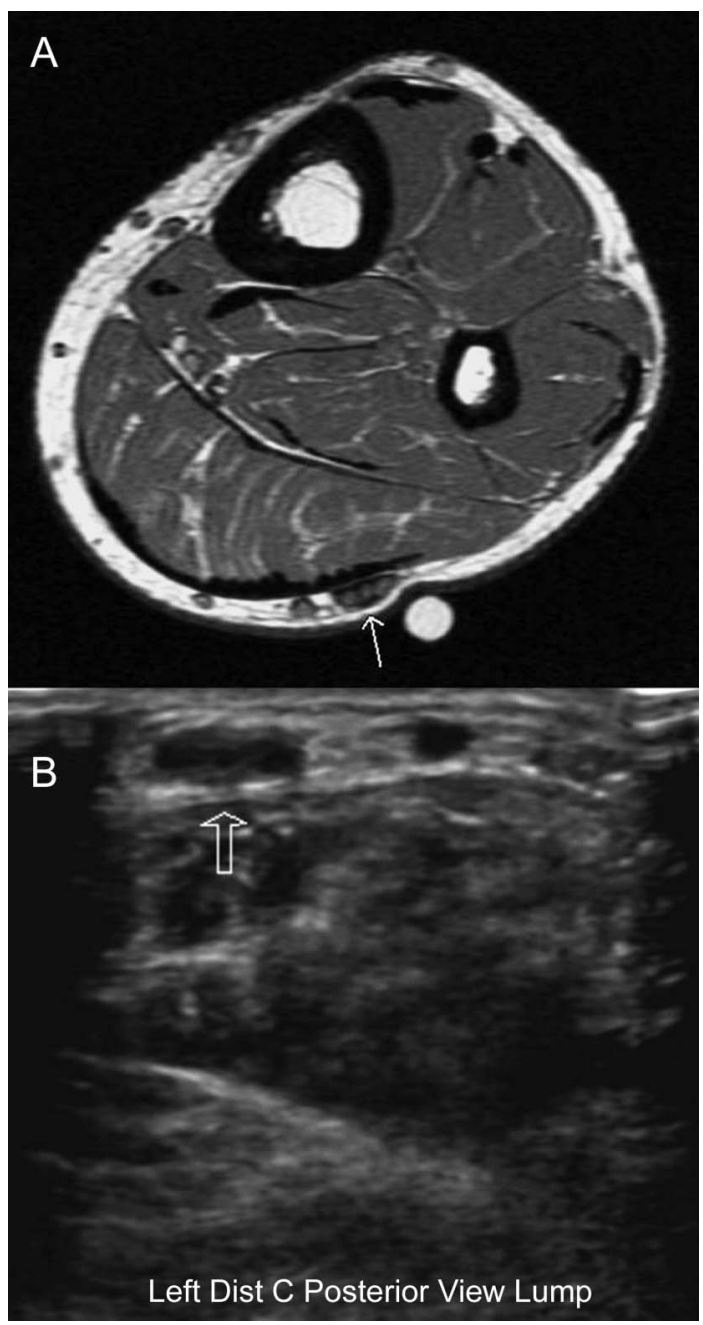

(A) Left lower extremity MRI (T1 sequence) shows sural nerve enlargement (arrow) with areas of mild enhancement suggestive of active inflammatory changes and decreased signal consistent with scarring. (B) Ultrasound demonstrates focal dilation of the sural nerve measuring $4.0 \mathrm{~mm} \times 8.0 \mathrm{~mm}$ (arrow).

A 42-year-old man with lepromatous leprosy treated with dapsone, rifampin, and clofazimine developed erythema nodosum leprosum (ENL) and neuritis involving facial, posterior tibial, and sural nerves. These reactions were treated successfully with prednisone and thalidomide. Eight years later, he presented with painful paresthesias in the left calf and an enlarged, tender sural nerve. Steroids were ineffective. Nerve ultrasound and MRI revealed focal dilation (figure 1). Nerve biopsy was diagnostic of hypertrophic regenerative neuroma (figure 2); Fite stain and Mycobacterium leprae PCR were negative. Nontraumatic neuroma in a patient with treated Hansen disease may clinically mimic neuritis/ENL, perineurioma, or neurofibroma. 


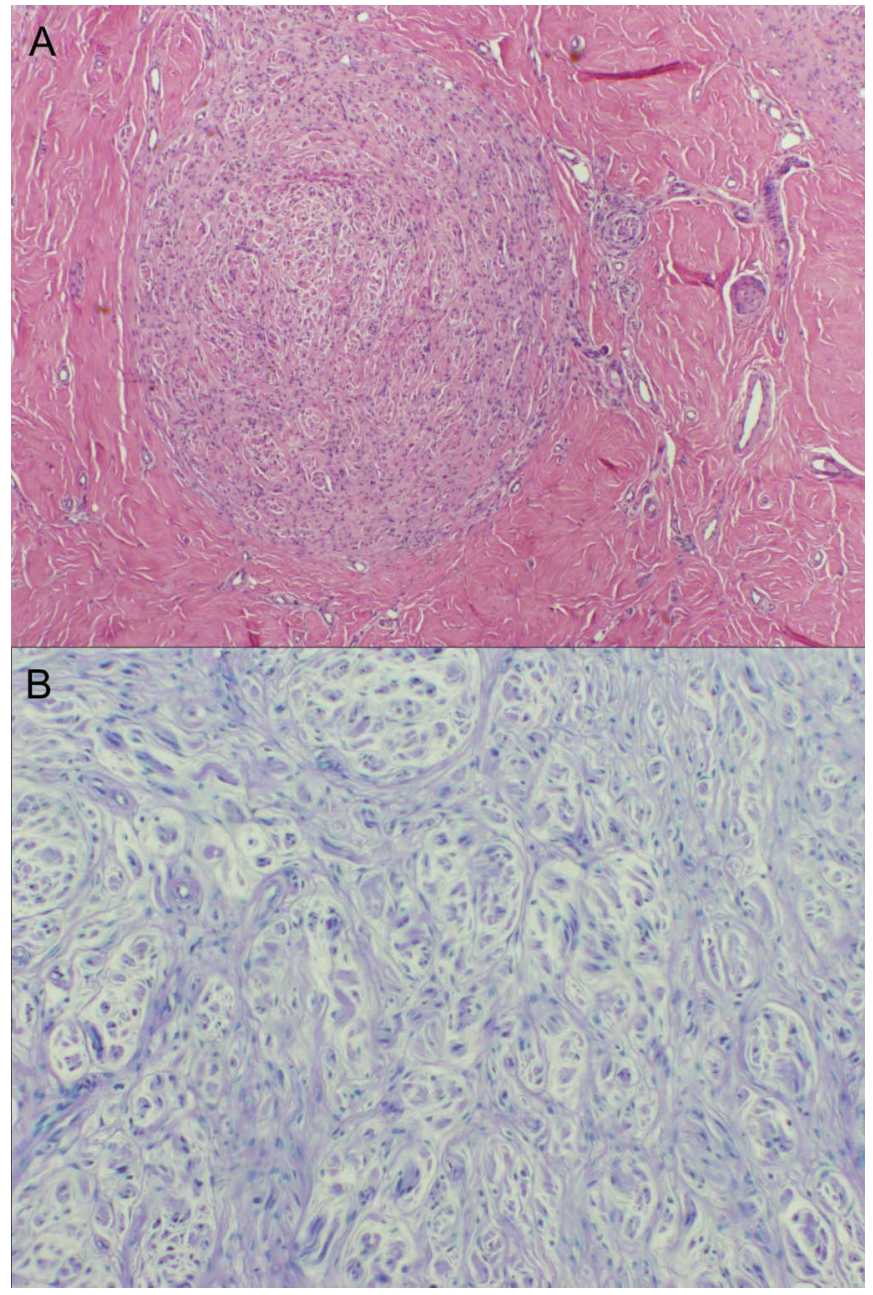

(A) Hematoxylin \& eosin shows dense fibrosis surrounding a nodule that has an appearance reminiscent of traumatic neuroma. No granulomas or inflammation are seen (original magnification 40×). (B) Luxol fast blue-periodic acid-Schiff stain demonstrates a disordered pattern of regenerating nerves and a paucity of myelinated fibers within the nodule (original magnification $100 \times$ ). Not shown: immunostains for CD45 and CD68 demonstrated small perivascular collections of lymphocytes and macrophages in the epineurium; S-100 immunostain showed small fibers in connective tissue; and epithelial membrane antigen was negative-whorls characteristic of perineurioma were not seen.

Christopher Parres, $M D$, Christine Thomas, $M D$, Winnie Ooi, $M D, M P H$, David Bryan, MD, Doreen Ho, MD, Jayashri Srinivasan, $M D, P h D, F R C P$

From Tufts Medical Center (C.P.), Boston; and Lahey Hospital \& Medical Center (C.T., W.O., D.B., D.H., J.S.), Burlington, MA.

Author contributions: Christopher M. Parres: drafting/revising the manuscript, analysis or interpretation of data, accepts responsibility for conduct of research and final approval, acquisition of data. Christine Thomas: drafting/revising the manuscript, analysis or interpretation of data, accepts responsibility for conduct of research and final approval, photomicrographs. Winnie Ooi: drafting/ revising the manuscript, study concept or design, accepts responsibility for conduct of research and final approval, study supervision. David Bryan: drafting/revising the manuscript, accepts responsibility for conduct of research and final approval, acquisition of data, was the operating surgeon. Doreen Ho: drafting/revising the manuscript, study concept or design, analysis or interpretation of data, accepts responsibility for conduct of research and final approval, study supervision. Jayashri Srinivasan: drafting/revising the manuscript, accepts responsibility for conduct of research and final approval, study supervision.

Study funding: No targeted funding reported.

Disclosure: The authors report no disclosures relevant to the manuscript. Go to Neurology.org for full disclosures.

Correspondence to Dr. Parres: cparres@tuftsmedicalcenter.org 


\section{Neurology}

\section{Nontraumatic hypertrophic neuroma in treated Hansen disease}

Christopher Parres, Christine Thomas, Winnie Ooi, et al. Neurology 2014;82;93-94

DOI 10.1212/01.wnl.0000438221.23814.68

\section{This information is current as of December 30, 2013}

\section{Updated Information \& Services}

\section{Subspecialty Collections}

Permissions \& Licensing

\section{Reprints}

including high resolution figures, can be found at: http://n.neurology.org/content/82/1/93.full

This article, along with others on similar topics, appears in the following collection(s):

\section{Post-infectious}

http://n.neurology.org/cgi/collection/postinfectious_

Information about reproducing this article in parts (figures,tables) or in its entirety can be found online at:

http://www.neurology.org/about/about_the_journal\#permissions

Information about ordering reprints can be found online:

http://n.neurology.org/subscribers/advertise

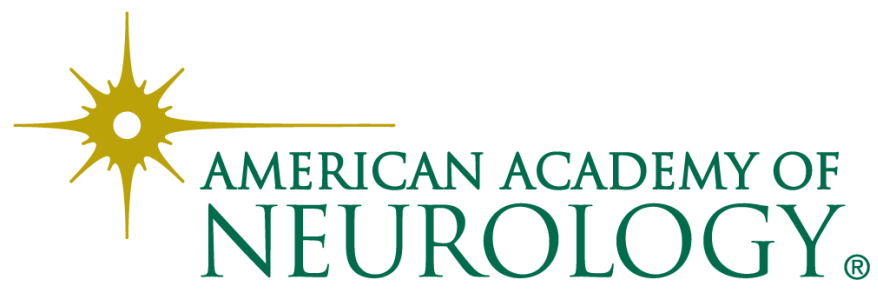

